\title{
IMPLEMENTING A “BLENDED LEARNING APPROACH” IN A SOCIAL WORK COURSE: THE PERCEPTIONS OF FIRST-YEAR STUDENTS AT A SOUTH AFRICAN UNIVERSITY
}

\author{
Roshini Pillay, Priscilla Gerrard
}

\section{INTRODUCTION}

Deep learning is an essential strategy that enables students to extract meaning and understanding from course material and experiences (Warburton, 2003). However, inculcating deep learning may prove challenging for facilitators in higher education in the South African context. Challenges usually arise because first-year students have to manage the difficult transition from high school to university. The difficulties of this transition are exacerbated by the fact that many students come from disadvantaged backgrounds characterised by an unevenly resourced, and sometimes dysfunctional, schooling system (Collins \& Van Breda, 2010; Leibowitz, 2010; Ross, 2010:461). Research by Muthivhi and Broom (2008) also reveals that, while the modes of teaching and learning employed by teachers in South Africa are inspired by the new curriculum framework and seem to meet the objectives of outcome-based education $(\mathrm{OBE})$, in reality these modes fail to instil deep learning in learners.

In an effort to improve the learning process for first-year Social Work students, the researchers - the first-year academic and field instruction co-ordinators at the University of the Witwatersrand (Wits) - redesigned the course on Health and Well-being using a blended approach. Qualitative evaluation methods were used to explore the perceptions of students regarding the use of online learning before and after taking the course. During this study the internet was used for online learning to access learning material and to interact with lecturers and peers to encourage the development of a community of practice. A community of practice is a group of people comprised of experts and novices who have similar interests and aspirations and work together to improve learning and understanding by supporting each other. Contact and support could occur through the use an electronic means of communication. Wenger (1998 cited in Rohleder, Swartz, Bozalek, Carolissen \& Leibowitz, 2008:133) notes that identification within a community of practice facilitates learning and leads to negotiability, which refers to the ability, facility and legitimacy to contribute to, and take responsibility for, shaping the meanings that matter within a social configuration.

This research study proved necessary as a literature review conducted by the researchers indicated that there is currently a paucity of research focusing on the blended learning approach in the South African social work teaching and learning context. It was envisaged that research of such a nature would contribute to enhancing the teaching and learning process for students and lecturers.

Attempts to improve throughput rates at Wits

The Wits Social Work Department faced possible closure in 2007, one of the main reasons being the low student throughput rates. A new selection procedure - which involved combining three criteria, namely the matriculation point system, scores on the Placement Test in English for Education Purposes (PTEEP) and the Social Work Biographical Questionnaire - was introduced in 2008 to address the problem (Ross, 2010:461).

As a means of building up the learning capacity of students, it also became compulsory for all Social Work students to attend an Academic Development Programme (ADP) in their first year 
498

at university. Although a slight improvement in the first-year pass mark was noted, approximately one third of the first-year Social Work students failed the exams during the period 2008 to 2010. In a further effort to improve the pass rate for first-year students it was decided to raise the academic admission criteria for 2011. It was also decided to de-modularise the Social Work courses and revert to year-long courses because the students' academic performance was found to improve slightly over the year and when writing end-of-year exams.

The researchers decided to utilise an innovative method to improve the teaching and learning process for first-year students. They did so by introducing a blended learning approach in the Wits Social Work Department. This approach focused on providing a greater range of learning options for students so that they could thereby customise their learning environment to meet their unique learning styles.

\section{The concept of blended learning}

There are many definitions of blended learning, but it basically combines the best of traditional approaches to teaching and learning with e-learning strategies (Garrison \& Vaughan, 2008; Mitchell \& Honore, 2007). At Wits e-learning is referred to as "any use of information and communications technology in teaching and learning or postgraduate studies to enhance or support student learning and research" (Keats, 2009a:3).

Dziuban, Hartman and Moskal (2004) also explain that blended learning is a pedagogical approach that combines face-to-face teaching with technology-enhanced active learning possibilities. Their definition emphasises the value of making students active participants in the teaching and learning process while, still maintaining a belief in the value of traditional pedagogical practices. Stacey and Gerbic (2008:965, citing Garrison \& Vaughan, 2008) describe the essence of the concept when stating that blended learning can be defined as "the thoughtful fusion of face-to-face and online learning experiences".

The components that made up the "blend" that was used when redesigning the first-year Social Work course on Health and Well-being are outlined in Figure 1. 
FIGURE 1

THE STRATEGIES ADOPTED IN THE BLENDED LEARNING SOCIAL WORK COURSE

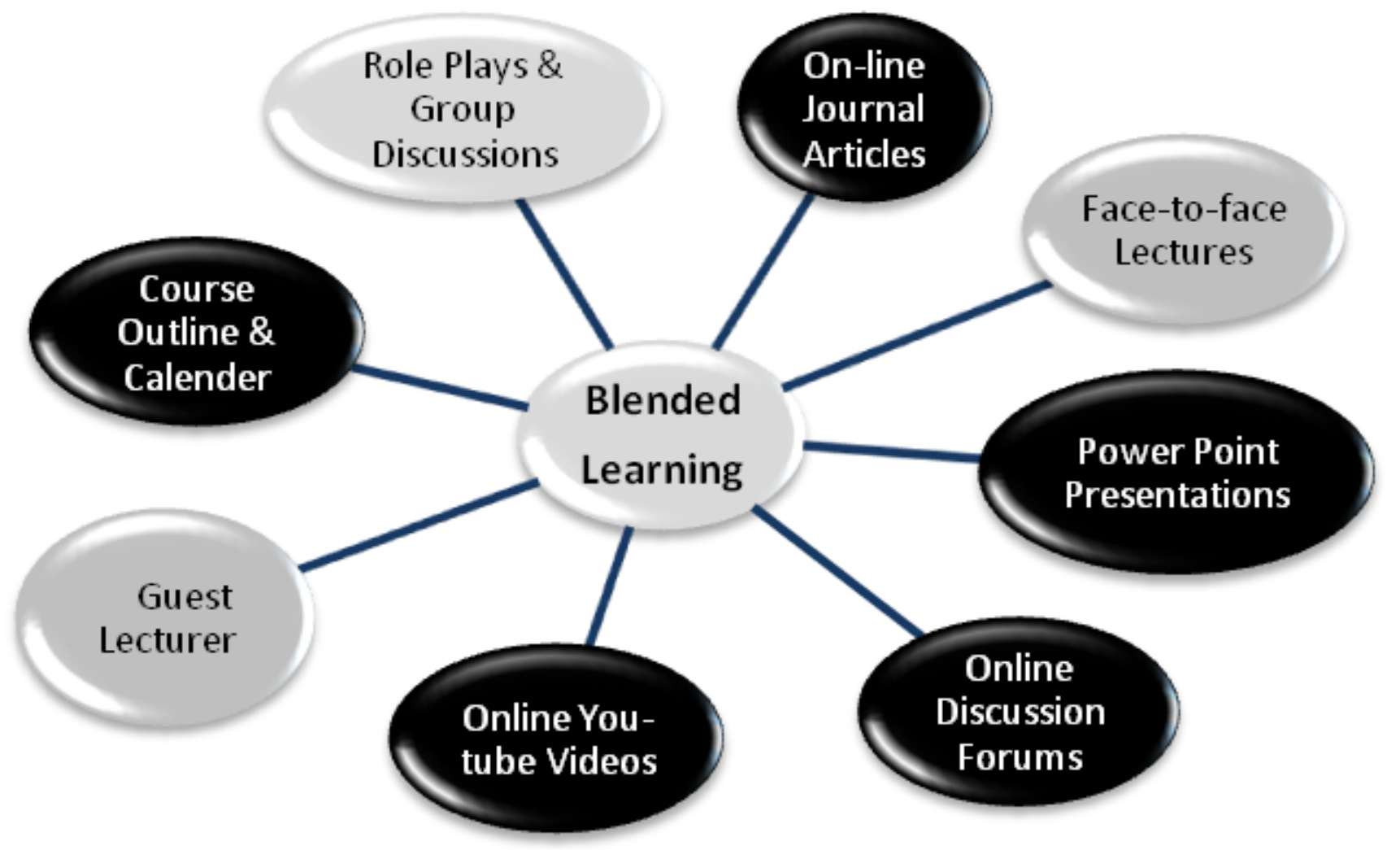

Traditional Strategies

The use of the blended approach represented in Figure 1 was in keeping with the teaching traditions of Wits, which is a contact university that has a strong emphasis on the classroom method of instruction. In this environment "e-learning is primarily used to support and supplement [the traditional] approach rather than to replace it" (Muller, 2010:2). Nevertheless, the development of e-learning has been recognised by Wits as important and is recorded in Goal 12 of the Teaching and Learning Plan (2010-2014:21) which stipulates: "By 2012 ... all courses will have an active e-learning presence which contains at least the essential information for the course and a facility which will allow all course participants to communicate electronically. All courses will have an appropriate blend of contact and electronic learning components that mutually support and enhance the learning experience" (University of the Witwatersrand, 2010).

Pedagogical approaches relevant to the e-learning components in a blended learning approach

Learning is a complex process (Collins \& Van Breda, 2010) and theories abound on the way learning occurs. However, the researchers identified two major learning theories that are directly applicable to the "blended" pedagogical approach, namely the theory of constructivism and the theory of connectivism. Constructivism defines learning as a social and active process involving the embedding of skills and knowledge in holistic and realistic contexts and using collaborative learning activities (Bellefeuille, 2006; Kilfoil, 2008; Vygotsy, 1978 cited in 
Dalgaard, 2006). According to Bloom's taxonomy (1956), it is also believed that this type of learning leads to deeper learning compared to surface learning in that "Students' activities in constructivist learning environments are initiated by a problem or project ... and tools and resources support the student's problem-solving process" (Dalgaard, 2006:4). Siemens (2006 as cited in Kilfoil, 2008:1020) defines learning as "a continual process in which knowledge is transformed into something of meaning through connections between sources of information and the formation of useful patterns, which generally results in something that can be acted upon appropriately, in a contextually aware manner". Siemens (2005) sees learning as a process of connecting specialised nodes or information sources; thus learning is seen as the act of encoding and organising nodes to facilitate connections between data, information and knowledge (Siemens, 2005). Within this connectivist theory e-learning provides learners with an openness of content and control of their own learning and allows lecturers to initiate, curate and guide aspects of that learning (Siemens, 2010).

The e-learning component of the blended learning approach is well aligned with constructivism, because it facilitates the active engagement of students with curriculum-related information in a variety of formats at a time and place that is suitable for them. E-learning also enables students to consciously reflect on what it is that they are learning and use their own experiences to transform this information into learning which is self-motivated and selfdirected. For example, the use of the discussion forum in the redesigned course provided the students with a space for self-expression and discussion, and facilitated students taking ownership of the knowledge and making it their own. It also gave the students time to consider the interpretations of other students of the questions posed and facilitated class discussions. In order to support this e-learning strategy, the lecturer requested that the students not just respond to a question posed, but also comment on the postings made by at least two other students. Presenting the PowerPoint slides of the lectures online provided the students with an opportunity to engage in structured learning. Another e-learning strategy implemented was that of YouTube videos. This exemplifies another benefit of e-learning in that it caters for learners who respond best to auditory and visual cues.

Aspects of the theory of connectivism were realised in the course when students had to make connections using various types of information in different formats, such as PowerPoint slides, YouTube videos and journal articles to construct essays and to respond to questions posed by the lecturer in the discussion forum. In this process the role of the lecturer was not to instruct but to support or facilitate the construction process, mainly by creating an environment in which construction can take place.

The Knowledge Environment for Web-based Learning (KEWL), an African, home-grown, learning-management system used initially by the University of the Western Cape, facilitates personalisation as students can upload their own pictures and customise their profiles on this online software programme (Stoltenkamp \& Kasuto, 2009). Thus students could develop their own learning environment which is in keeping with a relatively new approach to learning termed "autogogy". Autogogy refers to the way a person self-learns using $21^{\text {st }}$-century technology (Keats, 2009b). Using the KEWL learning management system, learners are able to create personal learning environments in order to manage their own learning and set their own learning goals.

The abovementioned theories formed the theoretical backdrop to the process of redesigning a first-year course in Social Work using the blended learning approach. 
The process of designing a course using the blended learning approach

Prior to 2010 Wits had made use of proprietary software called WebCT as a learning management system (LMS). However, the license for this system expires in 2011 and therefore the decision was made to consider a Free Open Source Software (FOSS) option, which is why KEWL was introduced in 2009 (Muller, 2010).

By embracing an open source software option, the e-learning component of the Health and Well-being course was designed using the KEWL system, even though this learning management system was still in the developmental stage. The designing of the course on KEWL took place over a period of three months, from May 2010 until July 2010, which was a relatively short period for redesigning a course in such a way that it incorporated the use of internet learning.

The course was divided into various themes, namely: Models of Health; Introduction to the SA Health System; HIV/Aids; Disability; Stress and Trauma; Traditional Healing and the Role of a Social Worker within the Health Care Setting. Students were provided with training and the opportunity to log onto the KEWL system at a workshop held in a computer lab on 14 July 2010. This session did not meet all the planned outcomes as many of the students were unable to $\log$ onto the system. These technical challenges proved frustrating both for the lecturer and students as valuable teaching time was wasted.

The redesigned Health and Well-being course was then implemented and evaluated to determine its effectiveness, based on the perceptions of the first-year students who completed the course. More specifically, the researchers wanted to explore the students' views on the suitability of using e-learning strategies such as online audiovisual material (e.g. YouTube videos) and online discussion forums to support face-to-face learning. The following research methods were used in conducting the research study.

\section{METHODOLOGY OF THE RESEARCH STUDY}

\section{Research design}

The primary aim of the study was to redesign a first-year Social Work course by adopting a blended learning approach and then to evaluate how the first-year Social Work students experienced the course when using e-learning strategies for the first time. The research design employed in the study entailed a descriptive, qualitative evaluation. Qualitative evaluation research is a form of applied research that is less structured than quantitative evaluation research; it studies the effects of a social intervention, which in this study was the redesigned course using a blended approach (Babbie, 2010). Using a time-series design, the students' views of blended learning were obtained prior to, and after, the redesigned course was presented to them.

\section{Sample}

Non-probability, purposive sampling was utilised as the sampling method. In this sampling method researchers choose participants based on their judgement that the individual participants possess most of the characteristics desired for the research (Rubin \& Babbie, 2010). The 2010 first-year Social Work class participated in the study, namely 41 females and 13 males. Three students chose not to participate in the pre-course group-administered questionnaire. Participants ranged in age from 17 to 24 years. The racial demographics of the class were 51 Black students (89\%) and 6 White students (11\%). 
Research instrumentation

To enhance the credibility of the qualitative research study, different research instruments were used, namely a one-question written survey, a group-administered survey questionnaire and a focus group schedule. An important strength of group-administered questionnaires is that they guarantee a high response rate and can be very versatile, allowing for a spectrum of open- and closed-ended types of questions (Colorado State University, 2010). An advantage of focus groups is that large amounts of concentrated data can be collected within a short period of time directly from the respondents, and research has shown that "people feel relatively empowered when supported in a group situation where they are surrounded by others" (De Vos, Strydom, Fouché \& Delport, 2005:301). The instruments were developed by the researchers and aligned with the primary aim of the research. The issues of reliability and validity were considered when designing the research instruments in the sense that research findings by previous researchers were taken into consideration when developing the instruments (Bellefeuille, 2006; Bersin \& Associates, 2003; Buzzetto-More, 2008).

Methods of data collection

Table 1 below illustrates the process adopted in gathering data for the study.

TABLE 1

PROCESS OF DATA COLLECTION

\begin{tabular}{|l|l|l|}
\hline \multicolumn{1}{|c|}{ Stages of data collection } & \multicolumn{1}{|c|}{$\begin{array}{c}\text { Tools and } \\
\text { strategies }\end{array}$} & \multicolumn{1}{c|}{ Number of participants } \\
\hline Pre-course data collection & $\begin{array}{l}\text { Group- } \\
\text { administered } \\
\text { questionnaire }\end{array}$ & $\begin{array}{l}54 \text { (3 did not complete the } \\
\text { questionnaire) }\end{array}$ \\
\hline Implementation of blended course & See Fig. 1 & 57 students \\
\hline Post-course data collection & Focus groups & $\begin{array}{l}\text { Focus group A: } 11 \\
\text { Focus group B: } 8\end{array}$ \\
\cline { 2 - 3 } & $\begin{array}{l}\text { Single open-ended } \\
\text { question survey }\end{array}$ & $\begin{array}{l}\text { 20 students (18 students did not } \\
\text { participate) }\end{array}$ \\
\hline
\end{tabular}

Data-gathering techniques were implemented at two stages of the research process, namely before the commencement of the Health and Well-being course, and after the completion of the said course. A group-administered questionnaire was completed in hardcopy by participants prior to the commencement of the Social Work course, the objective being to explore their previous experiences and perceptions regarding the use of e-learning. The use of an electronic survey was not available on the KEWL LMS, as this application was still being developed. Two separate focus groups, consisting of 11 and 8 participants respectively, were conducted by the researchers. Participants chosen were those who had engaged in the online discussion forum. All aspects of the blended learning approach that had been implemented in the course were discussed openly. After completion of the course 20 participants who had not been included in the focus groups responded in writing to a single, open-ended question regarding how they had experienced the blended learning course. These multiple methods of data collection were used to enhance the validity and credibility of the research. 


\section{Data analysis}

The results of the group-administered questionnaire were assembled in Excel format and descriptive statistics were used to analyse the closed-ended questions. Thematic content analysis as described by Cresswell (1988 as cited in De Vos et al., 2005:344) was employed to analyse the results of the open-ended items in the group- administered questionnaire, written responses to the single-question survey and focus group transcripts. Terre Blanche, Durrheim and Kelly (2006:321) point out that when researchers do thematic content analysis, it is important for them to stay close to the data as the purpose is to provide "a thick description of the 'characteristics', processes, transactions and contexts that constitute the phenomenon being studied". To enhance the validity of the study results, the researchers analysed the data independently and jointly discussed findings based on their analyses.

\section{Ethical considerations}

Clearance for the study was obtained from the University's Human Ethics Research Committee (Non-medical). Informed consent was obtained from the participants after the researchers had explained to them what the purpose of the research was. Participants were informed that engaging in the study by sharing their experiences of the blended course would have no impact on their academic grades. No coercion or perverse incentives were used, as such methods would have negated the principle of voluntary participation of the students. While the researchers were not able to guarantee anonymity, other than in the written questionnaire answers, the researchers took every step possible to ensure that, in writing up findings, confidentiality was maintained. The researchers verbally pointed out to focus group participants that confidentiality could not be guaranteed, but stressed the importance of not breaching confidentiality.

\section{FINDINGS}

\section{Pre-course findings}

A written questionnaire containing both open- and closed-ended questions was administered to 54 of the 57 students before the course was conducted - three students chose not to participate in answering the questionnaire which explored their perceptions regarding e-learning. Analysis of the findings was done through the use of descriptive statistics. Half of the total number of participants, namely 27 students $(50 \%)$, reported using the internet at university and 25 students $(46 \%)$ had access to this facility at home. Forty-four students $(81 \%)$ indicated that they did not experience difficulty accessing the internet. This view was confirmed by the fact that 34 students $(62 \%)$ noted that they made use of the internet on a daily basis. These results also indicated that the first-year Social Work students of 2010 reported regular use of social networking sites such as MXit, Facebook and even Twitter. In addition, their cell phone was another tool used to access the internet. These students therefore appeared to be digitally fluent and well connected as they interacted more regularly with friends, peers and even relatives online as compared to face-to-face. This information provided the researchers with the opportunity to consider the use of mobile technology for teaching and learning. These $21^{\text {st }}$ century learners gave the impression that they had positive attitudes towards the use of elearning and only three students $(6 \%)$ indicated that they did not believe that e-learning could enhance the teaching and learning process.

Although only 10 students (18\%) had made prior use of an e-learning programme in the form of WebCT in a Philosophy course; they reported that they were eager to engage with other students online and share their points of view on learning material. The students also rated 
highly the use of films and videos online as a method that could enhance face-to-face lectures, followed by the use of PowerPoint slides and class discussions. Features that students recommended be incorporated into e-learning materials included past exam questions, plagiarism software and self-administered tests.

\section{Post-course findings}

The findings of the study were categorised according to the nature of the components used in the course. The first category included traditional face-to-face teaching strategies, namely guest lecturers, role plays, group discussions and the use of PowerPoint slides during lectures. The second category included online components that facilitated the traditional teaching and learning approach, namely online PowerPoint slides, links to online journals, online course outline and course calendar. The third category included strategies that were novel and fundamentally different from the face-to-face approach, namely the online discussion forum and the use of YouTube videos. The themes that emerged from a thematic content analysis of the questionnaires are summarised below within the three categories discussed above.

\section{Category 1: Traditional teaching and learning Guest lecturers make a difference}

A second-year Social Work student who has a physical disability was invited to present her views regarding how the Wits community accommodates the needs of people with disabilities. Most students in the focus groups and in the one-question survey indicated that guest lecturers can definitely enrich the learning process. Some verbatim responses capturing this theme included the following:
... related to real life experience on Wits campus ... now more conscious to take the stairs than go up the ramps made for disabled.

Guest lecturer has much information related to life experience rather than just knowledge. She was talking from the heart-caught our interest.

\section{Utilize PowerPoint slides carefully in face-to-face lectures}

An important theme that came to light during the investigation was that Power Point slides can in fact undermine the learning process if not used correctly by the lecturer. This theme reinforces other research findings that have emerged which highlight the idea that presentations to learners largely stand or fall on the quality, relevance and integrity of the content (Tufte, 2003). PowerPoint is a competent slide manager and projector, but it should supplement a presentation, not substitute it. One student advised:

PowerPoint should just be a summary of the points that are going to be discussed. The lecturer should know her stuff well enough just to look at the points and then discuss the information with the class.

\section{Small-group discussions in class stimulate the learning process}

According to Hamann, Pollock and Wilson (2010), small-group, face-to-face discussions are better for stimulating student engagement and critical thinking skills than large-class discussions. This finding also emerged in this research study. Fifty-one students (94\%) enjoyed engaging in small-group discussions in class. According to one student:

They make the lecture more interesting ... learnt more ... integrate work just learnt into the case study and then share it with the whole class. 
Category 2: Components that facilitate the traditional teaching and learning approach Online PowerPoint slides provide students with the opportunity to revise course material

The benefit of PowerPoint is continually debated (Tufte, 2003) and there are no compelling results to prove or disprove that this visual aid is more effective for learner retention than traditional presentation methods (Savoy, Proctor \& Salvendy, 2009). However, 40 of the students (74\%) supported the use of PowerPoint slides covering different lectures as this provided them with the opportunity to revise course material. A student explained:

If you're not concentrating in lectures or just having a bad day, you can always revise work covered in class.

\section{Journal articles build insight into course content}

In order to enhance the learning process, the lecturer linked journal articles to the KEWL course programme. Students were also advised to subscribe to a free online Social Work journal with the title The New Social Worker. Students generally expressed the view that they found this e-learning strategy improved the learning process, that they found the articles very interesting and this strategy provided greater insight into the course.

\section{Online communication with lecturer is meaningful}

The basis for implementing a successful blended approach is found in the theory of constructivism, which values facilitator-supported learning. For this reason the lecturer frequently communicated with the students online, thereby providing them with guidance, clarity and motivation. Students generally noted that they found the lecturer's online communication beneficial. One student stated:

\section{Lecturer kept us up to date with course developments. Much appreciated.}

Students did not mention how they experienced the online course outline and calendar.

Category 3: Online strategies that develop the traditional learning approach

Discussion forum provides an opportunity for all students to share their points of view

An important theme that emerged was that the online discussion forum provided students with the opportunity to express their points of view, if they did not have the self-confidence to speak in front of the entire class, or if they did not have the opportunity during the class to do because of time restraints or because class discussions were dominated by a few students. This theme was encapsulated in the following statements made by various students:

Being afraid to ask questions in front of class ... English not good and peers tend to laugh at people not able to express themselves well. Wish programme had been introduced earlier. It came to the rescue of some of us.

Gives students a chance to express thoughts coming to mind that they did not get a chance to express in class ... can express how you really feel.

Inspires you to do some study before making the comments, because you know other class members will be reading your comments.

Quite a few students experienced the discussion forum as stimulating and enriching as well as providing an opportunity to engage with other class members in an academic context. An example of this experience was evidenced in the following verbatim statement:

Hearing the different views of my colleagues is quite an enlightening experience. 
Through the discussion forum students are able to share their thoughts with peers and lecturers, which creates connections beyond the information the lecturer has provided (Siemens, 2010).

\section{YouTube Videos support the learning process}

By including audio-visual material online, the students' capacity to understand important concepts was improved. This theme was reflected in the following student quotes:

Watching YouTube you get more insight into what people are really feeling (i.e. person with a disability) - a deeper insight. Very moving; cried.

Found information easier to understand ... became an eye-opener [referring to video No arms, no legs, and no worries].

An interesting point for educators made by one of the students regarding the use of online audio-visual material was that it should be located at a site where they do not become distracted. The student explained:

Rather than just referring student to the YouTube site to watch a video, load it specifically on to the KEWL programme. One tends to become distracted watching similar or other videos that are available on the website. You can concentrate more on its applicability to class information - you get sidetracked more if you go to YouTube website.

Blended approach to the course was "blemished" for some students

Fifty-one students (92\%) enjoyed the computer-assisted activities in the Social Work course; they found it beneficial and expressed the desire to have it used for other Social Work courses. One student captured the general view when stating:

I found this was the way to do the course because it was an approach for everyone to benefit from: if I find it difficult to pick things up in lectures, you could get important information from the guest speaker or the KEWL website. It's broad enough for everyone to find what they work best with.

However, three students, mainly the top academic achievers, stated that e-learning was a waste of time. As pointed out by one of the students who did not regard e-learning as necessary:

Performing well academically; do not see the reason to enhance the learning process.

Although the survey conducted prior to the implementation of the course gave the researchers the impression that all students would have easy access to computers and be able to log onto the course on the KEWL program, some verbatim responses revealed otherwise. One student summarised his frustration by describing the blended approach used in the course as the "blemished approach".

Other students explained:

...hardly have time for e-learning. It requires that you have your own computer. Some of us have to travel from campus to home every day, and this takes time.

Computers not always available at the time you have free from lectures.

Twenty-three students (40\%) found it difficult to use the KEWL program. Verbatim responses highlighting this theme included:

Freezes when opening the discussion forum. 
Moves very slow; it goes back and forth; back and forth.

Quite complicated to use... a lot of tabs to click.

\section{DISCUSSION AND CONCLUSIONS}

Conducting this research study was a learning experience for both the researchers and the firstyear students. The researchers also came to the early conclusion that redesigning a course using a blended approach can be a complicated process requiring technical competence and awareness of pedagogical opportunities. It was thus vital that onsite training was available to provide ongoing support and direction. Educators should also experiment with new technologies and pedagogies to adapt their teaching approach to suit the changing context (Siemens, 2010). The literature indicated that new learning technologies such as podcasting, vodcasting, e-portfolios and social networking tools such as blogs and wikis and so forth, have the potential to be creatively incorporated into a blended learning approach (Bozalek \& Matthews, 2009; Stacey \& Gerbic, 2008).

Many experts in the field of blended learning encourage the development of communities of practice for lecturers using FOSS, which would be an ideal way to develop and share e-learning best practices in higher education institutions (HEIs) and specifically in the field of social work (Stacey \& Gerbic, 2008; Wenger, 1998). The University of the Western Cape has already made significant strides in implementing e-learning strategies as they have "developed several online courses in Social Work which demonstrate deep learning (Bozalek \& Matthews, 2009 cited in Collins, Pretorius, Smith \& Van Breda, 2009:6). These would thus be a valuable components of the community of practice in HEIs. By sharing methods and teaching styles, the process of implementing a blended learning approach when designing Social Work courses would become more effective. HEIs promoting e-learning should also bear in mind that the blended learning approach should be introduced as a scholarly and transformative redesign process within the institution, one that rebuilds the course rather than simply adding on technology (Collins \& Van Breda citing Reeves \& Reeves, 2010; Garrison \&Vaughan, 2008).

Most students in the research study had no previous experience of using e-learning strategies and it was therefore understandable that their self-efficacy on the e-learning platform would have been compromised. A successful means of addressing this shortcoming is the establishment of an open communication process that facilitates guidance and direction for online participation. It is also important that educators implementing the blended approach take into consideration the social, political and economic variables in the context of higher education. Further research exploring the "blended" approach would advance the successful implementation of various strategies of teaching and learning, especially their innovative, technological components.

\section{REFERENCES}

BABBIE, E. 2010. The practice of social research. Belmont, USA: Wadsworth.

BELLEFEUILLE, G.L. 2006. Rethinking reflective practice education in social work education: a blended constructivist and objectivist instructional design strategy for web-based child welfare practice course. Journal of Social Work Education, 42(1):85-103.

BERSIN \& ASSOCIATES. 2003. Blended learning: what works? [Online] Available: http:// www.e-learningguru.com/wpapers/blended bersin.doc [Accessed: 24/06/2010]. 
BLOOM, B. 1956. Bloom's taxonomy of cognitive learning. [Online] Available: http://www.teacherstoolbox.co.uk/T_Bloom.html\#. [Accessed: 07/12/2009].

BOZALEK, V. \& MATTHEWS, L. 2009. E-learning: a cross-institutional forum for sharing socio-cultural influences on personal and professional identity. International Social Work, 52(2):235-246.

BUZZETTO-MORE, N. 2008. Student perceptions of various e-learning components. Interdisciplinary Journal of E-Learning and Learning Objects, 4:113-121.

COLLINS, K.J. \& VAN BREDA, A. 2010. Academic support for first-year social work students in South Africa. Social Work/Maatskaplike Werk, 46(1):14-25.

COLlins, K.J., PRETORIUS, B,. SMITH, P. \& VAN BREDA, A. 2009. Teaching and learning experiences of first-year social work students in South Africa. Report for the Association of South African Social Work Educational Institutions. Bellville, South Africa.

COLORADO STATE UNIVERSITY. 2010. Writing@CSU. [Online] Available: http:// writing.colostate.edu/guides/research/index.cf. [Accessed: 23/10/2010].

DALGAARD, C. 2006. Social software: e-learning beyond learning management systems. [Online] Available: http://www.eurodl.org/materials/contrib./2006/Christian_Dalgaard.htm. [Accessed:13/10/10].

DE VOS, A.S., STRYDOM, H., FOUCHÉ, C.B. \& DELPORT, C.S.L. 2005. Research at grassroots - for the social sciences and human service professions $\left(3^{\text {rd }}\right.$ ed $)$. Pretoria: Van Schaik Publishers.

DE VOS, A.S., STRYDOM, H., FOUCHÉ, C.B. \& DELPORT, C.S.L. 2002. Research at grassroots - for the social sciences and human service professions $\left(2^{\text {nd }}\right.$ ed). Pretoria: Van Schaik Publishers.

DZIUBAN, C.D., HARTMAN, J.L. \& MOSKAL, P.D. 2004. Blended learning. Research Bulletin, (7):1-12.

GARRISON, D.R. \& VAUGHAN, N.D. 2008. Blended learning in Higher Education: framework, principles and guidelines. United States of America: John Wiley Sons Inc. [Online] Available: http://www.amazon.com/gp/reader/0787987700/ ref= sib dp_ptu\#reader-link [Accessed: 22/11/2010].

HAMANN, K., POLLOCK, P. \& WILSON, B. 2010. Comparing the benefits of small-group and large-class discussions. APSA 2010 Teaching \& Learning Conference Paper. [Online] Available: http://papers.ssrn.com/sol3/papers.cfm?abstract id=1544620\#\#. [Accessed: 22/11/2010].

KEATS, D. 2009a. e-learning strategy and tactics. Draft for public comment, Johannesburg.

KEATS, D. 2009b. Challenges for quality assurance in an education 3.0 world. PowerPoint Slides. [Online] Available: http://www.unesco.org/education/ hed/quality/keats.pdf [Accessed: 25/10/2010].

KILFOIL, W.R. 2008. A model for learning development. South African Journal of Higher Education, 22(5):1019-1028. 
LEIBOWITZ, B. 2010. Towards scholarship of teaching and learning as critical engagement: a perspective from the "South". International Journal for the Scholarship of Teaching and Learning, 4(2). [Online] Available: https://www.georgiasouthern.edu/ijsot [Accessed: 15/10/2010].

MITCHELL, A. \& HONORE, S. 2007. Criteria for successful blended learning. Industrial and Commercial Training, 39(3):153-149.

MUTHIVHI, E. \& BROOM, Y. 2008. Continuities across schooling transition: a case of classroom: practices among teachers in Venda, South Africa. Journal of Educational Studies, 7(1):98-121. [Online] Available: http://web.uct.ac.za/depts/educate/download/jes08. pdf [Accessed: 05/05/2011].

MULLER, C. 2010. KEWL - an open source learning management system: a practitioner's analysis of an e-learning system at WITS. Unpublished.

ROHLEDER, P., SWARTZ, L., BOZALEK, V., CAROLISSEN, R. \& LEIBOWITZ, B. 2008. Community, self and identity: participatory action research and the creation of a virtual community across two South African universities. Teaching in Higher Education, 13(2):131143.

ROSS, E. 2010. Selection tests and social justice: a profile of applicants seeking admission to the social work undergraduate degree at a South African university. Social Work Education, 29(5):459-474.

ROWE, M. 2009. Knowledge and attitudes regarding the use of social software in a physiotherapy department. JCHS, 4(1):1-6.

RUBIN, A. \& BABBIE, E. 2010. Essential research methods for social work (2 $\left.{ }^{\text {nd }} \mathrm{ed}\right)$. California: Belmont.

SAVOY, A., PROCTOR, R. \& SALVENDY, G. 2009. Information retention from PowerPoint $^{\mathrm{TM}}$ and traditional lectures. Computers \& Education, 52(4):858-867.

SIEMENS, G. 2005. Connectivism: learning as network-creation. [Online] Available: http://www.astd.org/LC/2005/1105_siemens.htm [Accessed: 22/10/2010].

SIEMENS, G. 2010. ERN-mobiles, Meeker report, facebook and activity streams. [Online] Available: https://mail.google.com/mail/?hl=en\&shva=1\#inbox/12c58953e00b0101 [Accessed: 22/11/2010].

STACEY, E. \& GERBIC, P. 2008. Success factors for blended learning. Proceedings ascilite Melbourne: Concise Paper. [Online] Available: www.ascilite.org.au/conferences/melbourne 08/procs/stacey.pdf [Accessed: 24/10/2010].

STOLTENKAMP, J. \& KASUTO, O.A. 2009. e-learning change management and communication strategies within a HEI in a developing country: institutional organisational cultural change at the University of the Western Cape. Educ Inf Technol, 1-14.

TERRE BLANCHE, M., DURRHEIM, K. \& PAINTER, D. 2006. Research in practice: applied methods for the social sciences. Cape Town: University of the Cape Town Press.

TUFTE, E. 2003. PowerPoint is evil. [Online] Available: http://www.wired.com/wired/ archive/11.09/ppt2.html [Accessed: 22/11/2010]. 
510

UNIVERSITY OF THE WITWATERSRAND. 2010. The teaching and learning plan 2010 to 2014. Unpublished document.

WARBURTON, K. 2003. Deep learning and education for sustainability. International Journal of Sustainability in Higher Education, (4)1:44-56. [Online] Available: http://www. emeraldinsight.com/journals.htm?articleid=839800\&show=abstract [Accessed: 06/05/2011].

WENGER, E. 1998. Communities of practice: learning, meaning and identity. Cambridge: Cambridge University Press.

Ms Roshini Pillay, Ms Priscilla Gerrand, Department of Social Work, University of the Witwatersrand, Johannesburg, South Africa. 